\title{
Ortaokul Görsel Sanatlar Dersinin Öğrenme-Öğretme Sürecine İlişkin Öğretmen Deneyimleri ${ }^{1}$
}

\begin{tabular}{lccc}
\hline MAKALE TÜRÜ & Başvuru Tarihi & Kabul Tarihi & Yayım Tarihi \\
Araştırma Makalesi & 09.04 .2021 & 14.11 .2021 & 15.11 .2021 \\
\hline
\end{tabular}

\section{Nergiz Üçüncü Altuğ iD ${ }^{2}$}

Uludağ Üniversitesi

\author{
Ayşe Çakır İlhan (iD ${ }^{3}$ \\ Ankara Üniversitesi
}

\begin{abstract}
Öz
Görsel sanatlar dersi, kuramsal ve uygulamalı yapısıyla öğrencilerin kişisel, sosyal ve kültürel gelişimlerini sağlamak için düzeye uygun içerikler sunmayı amaçlamaktadır. Sanat tarihi, sanat eleştirisi, estetik disiplinleriyle bilginin yorumlanmasını; uygulama çalışmasıyla bireysel ifadenin üretilmesi gerçekleştirilir. Toplumda bilinçli sanat izleyicisi yetiştirilmesine katkı sağlamaktadır. Araştırmada, ortaokul görsel sanatlar dersinin öğrenme-öğretme süreci, uygulama çalışması ile ölçme ve değerlendirme yöntemlerine ilişkin öğretmenlerin deneyimleri derinlemesine incelenmiştir. Araştırma, temel nitel araştırma desenine göre şekillendirilmiş, öğrenme-öğretme sürecinin çözümlenmesi ve yorumlanmasına odaklanılmıştır. Çalışma grubu Ankara ve Bursa ilinde çalışan 13 görsel sanatlar öğretmeninden oluşmaktadır. Veriler gözlem ve görüşme aracıllğ̆ıla toplanmıştır. Gözlem ve görüşme verileri çözümlenmiş ve içerik analizi aşamaları kullanılarak araştırmaya yönelik kavramlara ulaşılmıştır. Görsel sanatlar öğretmenlerinin disiplin odaklı sanat eğitimi yaklaşımını kullanması, derste tasarım ve bireysel ifadenin geliştirilmesi, uygulama çalışmasında konu seçimi ve öğrenci düzeyine uygunluğu, ölçme ve değerlendirme sürecinin planlanması ve uygulanmasına yönelik bulgular ortaya çıkarılmıştır. Görsel sanatlar öğretmenlerinin etkili bir öğrenme ortamı sağlaması için ders sürecini öğrencilerin zekasına, ilgilerine ve duygularına hitap edebilecek içeriklerle tasarlaması hem farklı özellikte öğrencilere ulaşmasını hem de öğrencilerin çok yönlü gelişmesini sağlayabilir. $\mathrm{Bu}$ nedenle görsel sanatlar dersinin varolan fiziksel koşullara uygun olarak planlanması ve diğer disiplinlerle ilişki kurulması konusunda öğretmenlerin desteklenmesinin alanın gelişmesine katkı sağlayacağı düşünülmektedir.
\end{abstract}

Anahtar sözcükler: Sanat eğitimi, görsel sanatlar eğitimi, ortaokul, görsel sanatlar öğretmeni.

Etik kurul kararı: Bu araştırma, Ankara Üniversitesi etik kurul onayına (No: 85434274050.04.04/27013, Tarih: 25.04.2019) sunulmuştur.

${ }^{1} \mathrm{Bu}$ araştırma Ankara Üniversitesi Eğitim Bilimleri Enstitüsü’nde Prof. Dr. Ayşe Çakır İlhan danışmanlığında yürütülen "Görsel Sanatlar Öğretmenlerine Yönelik Mesleki Gelişim Modülü Geliștirilmesi" adlı doktora tezinden üretilmistir.

${ }^{2}$ Sorumlu Yazar: Arş. Gör. Dr. Eğitim Fakültesi, Güzel Sanatlar Eğitimi Bölümü, Resim-İş Eğitimi Anabilim Dalı, E-posta: nergizucuncu@ gmail.com, https://orcid.org/0000-0002-9975-9302

${ }^{3}$ Prof. Dr. Eğitim Bilimleri Fakültesi, Güzel Sanatlar Eğitimi Bölümü, E-posta: ilhan@ankara.edu.tr, https://orcid.org/0000-0003-1236-711X 
Sanat eğitimi, 20. yüzyılın başından itibaren tüm sanat alanlarını ve biçimlerini içine alan, okul içi ve okul dışı yaratıcı eğitim süreci olarak tanımlanmaktadır (San, 2010). Sanat eğitimi ile öğrencilerin profesyonel birer sanatçı olmayacağı fakat hepsinin sorumlu birer dünya yurttaşı (Freedman ve Stuhr, 2004) ve bilinçli sanat tüketicisi olmalarına vurgu yapılmaktadır. Görsel sanatlar dersi, kaynağını sanat ve kültürden alan geniş bir arka plana sahiptir. Bu nedenle görsel sanatlar dersinin öğrencilere sanatın düşünsel temelleri, kavramları ve sanat yapma süreçlerinin çözümlenmesi gibi konuları ele almasının yanında, en önemli özelliği bilginin yorumlanmasını ve üretilmesini sağlamaktır (Aykut, 2012). Örgün eğitimde görsel sanatlar dersinin bireyin duyuşsal, bilişsel ve psikomotor gelişimine katkısı ve üst düzey düşünme becerilerini geliştirmesindeki rolü oldukça önemlidir.

Geleneksel sınıflarda bilginin aktarılışı ile ilgili olarak Dewey (çev. 1938, 1998) öğrencilerin sınıf içinde edindikleri deneyimlerin, eğitime yönelik olumsuz tutum geliştirmelerine yol açtığını belirtmiştir. Yaşamdan kopuk bilginin kullanılması, doğru olana ulaşma amacı ve bilgilerin haftalara bölünerek bağlantısız aktarılması yerine, öğrencilerin nasıl öğrenecekleri ve nasıl düşüneceklerine (Fisher, 1999) ilişkin konular öğrenme öğretme süreçlerinde önem kazanmıştır. Ekonomik İşbirliği ve Kalkınma Örgütü (Organisation for Economic Co-operation and DevelopmentOECD) eğitim ve öğretim direktörü Schleicher, "dünya ekonomisinin artık bilinenlerle ilgilenmediğini çünkü Google'ın zaten her şeyi bildiğini”" dile getirmiştir (Robinson ve Aronica, çev. 2017, s. 189). Böylece öğrencilerin geleceğe hazırlanmasında bilgi aktarımı anlayışının günümüz teknolojisi karşısında yetersiz kaldığı belirtilmiştir. Dünyada dijital devrim olarak nitelendirilen dördüncü sanayi devrimi ile bilginin kazanılmasına dayanan temel yetkinliklerin ötesinde, toplumu oluşturan bireylerin çözme, eleştirel düşünme, yaratıcılık, insanları yönetme, diğer insanlarla eşgüdüm sağlayabilme, duygusal zekâ, yargı ve karar verme, hizmet oryantasyonu, müzakere ve bilişsel esneklik gibi becerilere sahip olmaları beklenmektedir (Karip, 2016).

Ülkemizde 1990 yılında başlatılan eğitimde yeniden yapılanma süreciyle birlikte bireylerin düşünme ve bilgiyi kullanma becerilerinin geliştirilmesi önem kazanmaya başlamıştır. 2005-2006 öğretim yılında Milli Eğitim Bakanlığı Talim ve Terbiye Kurulu Başkanlığı tarafından yapılan ortaöğretim programlarının yapılandırmacı anlayışla yenilenmesiyle bireylerin bilişsel gelişimlerinin öncelendiği eğitim hedefleri benimsenmiştir. Bilişsel kuramlar, öğrencilerin bilgiyi farklı ortamlarda nasıl kullanacaklarını anladıkları zaman eğitimde bilgi ya da beceri aktarımının gerçekleşeceğini öne sürmektedir (Schunk, 2011). Yapılandırmacı öğrenme yaklaşımı, "kalıcı öğrenmeler sağlayacak üst düzey beceriler geliştirmeyi hedefler. Bu yaklaşımda öğrenci etkin olarak öğrenme ortamının merkezinde yer alır” (Gözütok, 2017, s. 179). Bilginin otoriter bir öğretmenden edilgin öğrenciye aktarılması yerine, bilginin oluşturulmasında anlamlı etkileşimin gerçekleştiği, düşüncelerin paylaşıldığı ve ortak anlayışın oluşturulduğu üst düzey iletişim ortamının sağlanması beklenmektedir (Anderson ve Milbrandt, 1998). 
1994-1998 yıllarında Milli Eğitimi Geliştirme Projesi kapsamıyla Görsel sanatlar dersi öğretim programları Disiplin Odaklı Sanat Eğitimi yaklaşımı ile yapılandırılmıştır. Disiplin odaklı sanat eğitimi yaklaşımı önce sanat öğretmeni yetiştiren kurumlara, daha sonra temel eğitim ve orta öğretim kurumlarına yansımıştır (Kırışoğlu, 2009). Öğretmenlerin ders içeriğini planlamada, sanat tarihi, sanat eleştirisi, estetik ve uygulama disiplinlerinden yararlanarak görsel sanatlar dersini kuram ve uygulamada ele alması sağlanmıştır. 2006 Görsel Sanatlar Dersi Öğretim Programında eğitim ve sanat eğitiminde yapılan reformlar şu şekilde belirtilmiştir:

Günümüz bilişim çağında, yaratıcı, girişimci, sorun çözücü, bilgiyi yapılandırıcı ve dönüştürücü bireylere ihtiyaç duyulmaktadır. Özellikle çoğu gelişmiş ve bazı gelişmekte olan ülkelerde "Yapılandırmacılık” biçiminde tanımlanan "öğrenci merkezli" yeni bir eğitim uygulama modelinin hayata geçtiği gözlenmekte, bu modelin çağın ve günün gereklerine daha uygun olduğu düşünülmektedir. (Milli Eğitim Bakanlığı-MEB, 2006, s. 6)

2013 ve 2018 Görsel Sanatlar Dersi Öğretim Programları da disiplin odaklı sanat eğitimi yaklaşımı benimsenerek yapılandırmacı eğitim felsefesine yönelik oluşturulmuştur. Disiplin odaklı sanat eğitimi yaklaşımının benimsenmesinde, sanat alanlarının ve disiplinlerinin nasıl aktarılacağının belirlenmesi ve eğitim süreçleri ile uygulamalarının ele alınması gereklidir. $\mathrm{Bu}$ nedenle sanat eğitiminde öğretmenin neyi, niçin öğreteceğini bilmesi, açık ve anlaşılır bir amaca bağlı olarak öğrencinin ne öğreneceğine ilişkin saptama yapabilmesi gerekmektedir (Kırışoğlu, 2005). Bu nedenle San (2010), sanat eğitimi ile sanat öğreniminin birbirinden ayrışması için sanat eğitimi alanının akılcı ve bilimsel temellere oturtulması gerektiğini belirtmiştir. Eisner (2001), sanat eğitiminin sanat öğretisinden daha kapsamlı olduğunu belirtmiştir.

Sanat eğitiminin, örgün eğitim programında yer aldığı dönemden günümüze kadar geçen sürede, kuram ile mevcut durum arasında büyük bir çelişkinin oluştuğu görülmektedir. Kırışoğlu (2005), genel eğitim dizgesi içinde sanat eğitimini, olması gereken ile var olan durumların sürekli çeliştiği bir alan olarak açıklamıştır. Bu çelişkinin kaynağını sadece eğitim sisteminin sınavlarla ilerlemeyi gözeten yapısı olarak görmenin dışında, sanat eğitimi kurumlarını sorunları ve çözüm önerileriyle birlikte ele almak gerekmektedir. Görsel sanatlar öğretmenlerinin, öğretim programını uygulama sürecinde karşılaştıkları sorunlarla ilgili Sarı (2011) doktora tezinde, 2006 yılı öğretim programının aile ve çevresel etkenler, öğretmen sayısının yetersizliği, programın öğrencilerin ilgisini çekmemesi, sınıfların kalabalık olması, programın uygulanması kapsamında yeterli bilgi olmaması ve zamanın yetersizliği gibi etkenler nedeniyle uygulanabilirliğinin düşük olduğu sonucuna ulaşmıştır.

Görsel sanatlar öğretmenlerinin karşılaştıkları sorunların araştırıldığı bir makalede Cömert (2019), 16 ortaokul görsel sanatlar öğretmeni ile yaptığı görüşme sonucunda ders saatlerinin yetersiz olması, dersin sınıf ortamında yapılmasının uygun olmadığı, dersin uygulanmasını zorlaştıran kalabalık sınıflar, derse önem vermeyen birçok veli ile malzemenin sağlanması ve aksayan öğretim programları araştırma 
sonucu olarak elde edilmiştir. Görsel sanatlar öğretmenleri, fiziksel koşulların dersin uygulanmasında önemli oranda etkisinin olduğunu belirtmektedir. Ayrıca görsel sanatlar dersine ilişkin velilerin tutumu ile ilgili olarak Çakmak ve Türkcan (2019), velilerin gelecekteki meslek seçiminde resmin yeri olmadığını düşündüğü için derse yönelik olumsuz tutum geliştirdiklerini belirtmiştir.

Görsel sanatlar öğretmenlerinin öğrenme-öğretme sürecinde karşılaştıkları sorunların çözümünde sıklıkla Görsel Sanatlar Platformu (www.gorselsanatlar.org) paylaşımlarından yararlanıldığ 1 görülmektedir. Haziran 2007'den itibaren aktif olan forumun, güncel üye sayısı yaklaşık 90 bin civarındadır. Forumda görsel sanatlar dersinin öğrenme-öğretme sürecine yönelik farklı içerikler yer almakta ve ağırlıklı olarak yıllık plan paylaşımları bulunmaktadır.

Namdar ve Önder (2019) Türkiye'de ilköğretim görsel sanatlar dersi ile ilgili 2016 yılının sonuna kadar yapılan 84 lisansüstü tezin içerik analizini yaptığı araştırmasında, lisansüstü tezlerin öneriler başlığ incelendiğinde, hizmet içi eğitim ve seminerlerin verilebileceği, sanat eğitimi ortamlarının gerekli materyallerle donatılması gerektiği, görsel sanatlar ders süresinin artırılması ve müzelerle işbirliği yapılması gerektiğinin en sık tekrar edilen öneriler olduğuna ulaşılmıştır.

Alanyazında yapılan araştırmalar incelendiğinde fiziksel koşulların geliştirilmesine sıklıkla yer verilmiştir. Ayrıca öğretmen eğitimine ve görsel sanatlar dersine karşı tutuma ilişsin sorunlar olduğu belirlenmiştir. Ancak görsel sanatlar dersinin öğrenme-öğretme sürecinde öğretmenlerin karşılaştıkları durumların neler olduğu, fiziksel koşullara uygun olarak görsel sanatlar dersinin nasıl geliştirilebileceği ve diğer disiplinlerle nasıl ilişki kurulabileceği gibi soruların ele alınması gerekmektedir. $\mathrm{Bu}$ araştırmada, ortaokul görsel sanatlar dersinde öğretmenlerin öğrenme-öğretme sürecine yönelik olarak deneyimlerinin derinlemesine araştırılması amaçlanmaktadır. Bu amaca yönelik olarak aşağıdaki sorulara yanıt aranmıştır:

1. Görsel sanatlar dersinin kuramsal bölümü nasıl gerçekleştirilmektedir?

2. Görsel sanatlar dersinde uygulama çalışması süreci nasıl gerçekleştirilmektedir?

3. Görsel sanatlar dersinde ölçme ve değerlendirme süreci nasıl gerçekleştirilmektedir?

\section{Yöntem}

$\mathrm{Bu}$ bölümde araştırma modeli, çalışma grubu, veri toplama araçları, verilerin analizi, araştırmanın geçerlik ve güvenirliğine ilişkin bilgiler yer almaktadır.

\section{Araştırma Modeli}

$\mathrm{Bu}$ araştırmada, ortaokul görsel sanatlar öğretmenlerinin ders sürecinde oluşturdukları deneyimler ve derse yönelik geliştirdikleri anlam ortaya konularak varolan durumun yorumlanması araştırmanın odağını oluşturmaktadır. Bu nedenle araştırmada, temel (yorumsamacı) nitel araştırma deseni kullanılmıştır. Nitel 
araştırma anlamın nasıl inşa edildiği ile ilgilenir; temel nitel araştırma ise, bu anlamın ortaya çıkarılması ve yorumlanmasını içermektedir. Temel nitel araştırmada anlam oluşturulmuş ancak keşfedilmemiştir. Temel (yorumsamacı) nitel araştırma deseni, eğitim gibi uygulamalı alanlarda en yaygın kullanılan araştırma biçimidir. Bir sınıfta öğretme-öğrenme sürecini anlamaya yönelik varolan durumun belirlenmesi ve yorumlanmasına ilişkin araştırmalar temel nitel araştırma deseni kullanılarak yapılmaktadır (Merriam, çev. 2013). Bu nedenle temel nitel araştırma deseni kullanılarak ortaokul görsel sanatlar dersinin öğrenme-öğretme sürecinin çözümlenmesine ve yorumlanmasına odaklanılmıştır.

\section{Çalışma Grubu}

$\mathrm{Bu}$ araştırmada, ortaokul görsel sanatlar dersinin varolan durumunun ortaya konulması için devlet okullarında görev yapan görsel sanatlar öğretmenleri ile çalışılmıştır. Çalışmada yer alacak okulların ve öğretmenlerin belirlenmesinde kolay ulaşılabilir durum örneklemesi kullanılmıştır. Kolay ulaşılabilir durum örneklemesinde araştırmacı, diğer örnekleme yöntemlerini kullanma olanağının bulunmadığ (Yıldırım ve Şimşek, 2008). Araştırmacının, Ankara ve Bursa'da ikamet etmesi nedeniyle bu iki ilde yer alan devlet okullarının belirlenmesi uygun görülmüştür. $\mathrm{Bu}$ kapsamda Ankara ve Bursa illerinde farklı sosyo-ekonomik düzeyde ilçeler belirlenmiştir. Alt, orta ve yüksek sosyo-ekonomik düzeylere göre, Ankara ilinde Mamak, Etimesgut ve Çankaya semtlerinden; Bursa ilinde Yıldırım, Osmangazi ve Nilüfer semtlerinden ortaokullar seçilmiştir.

Ankara ve Bursa illerinden beşer ortaokul olmak üzere 10 ortaokul belirlenmiş ve Millî Eğitim Bakanlığı'ndan araştırma izni alınmıştır. Araştırmanın çalışma grubunu, izin alınan ortaokullardan ve okul yönetiminin bilgisi dahilinde 13 görsel sanatlar öğretmeni oluşturmaktadır (Tablo 1). Öğretmenlerin çalışmaya katılımlarında gönüllü olduklarını bildiren Aydınlatılmış Onam Formu hazırlanmış ve öğretmenlere onaylattırılmıştır.

\section{Tablo 1}

Çalışma Grubunun Demografik Özellikleri

\begin{tabular}{lrrrr}
\hline Öğretmen kodu & Sınıf düzeyi & Öğrenci sayısı & Sınıf / atölye & Meslek yılı \\
\hline BUR/N1/E1 & 8. sinıf & 25 & Sinıf & 32 \\
BUR/N2/K2 & 6. sinıf & 31 & Atölye & 4 \\
BUR/N2/E3 & 5. sinıf & 32 & Atölye & 26 \\
BUR/O1/K4 & 6. sinıf & 33 & Sinıf & 4 \\
BUR/O2/K5 & 7. sinıf & 18 & Sinıf & 8 \\
BUR/O2/K6 & 8. sinıf & 21 & Sinıf & 10 \\
BUR/Y1/K7 & 7. sinıf & 17 & Sinıf & 6 \\
BUR/Y1/K8 & 6. sinıf & 26 & Sinıf & 16 \\
\hline & & & & (devam ediyor)
\end{tabular}


Tablo 1 (devam)

\begin{tabular}{lrrrr}
\hline Öğretmen kodu & Sınıf düzeyi & Öğrenci sayısı & Sınıf / atölye & Meslek yılı \\
\hline ANK/Ç1/K9 & $8 . \sin ı f$ & 33 & Sinıf & 28 \\
ANK/E1/K10 & 7. sinıf & 30 & Sinıf & 19 \\
ANK/E2/K11 & 7. sinıf & 28 & Sinıf & 24 \\
ANK/M1/K12 & 6. sinıf & 30 & Sinıf & 25 \\
ANK/M2/K13 & 5. sinıf & 35 & Sinıf & 6 \\
\hline
\end{tabular}

Çalışma grubunun demografik özelliklerinin yer aldığı tablonun ilk sütununda öğretmen kodları bulunmaktadır. Tabloya göre Ankara ili (ANK), Mamak (M), Etimesgut (E) ve Çankaya (Ç) olarak; Bursa ili (BUR), Yıldırım (Y), Osmangazi (O) ve Nilüfer $(\mathrm{N})$ şeklinde; erkek $(\mathrm{E})$, kadın $(\mathrm{K})$ olarak kısaltılarak öğretmen kodları oluşturulmuştur. Araştırmanın bulgularında bu kodlar kullanılmıştır. İkinci sütunda gözlem yapılan derslerin sınıf düzeyleri yer almaktadır. Ortaokul kademesinde yer alan sınıf düzeylerinin tümü araştırma sürecine dahil edilmiştir. Altıncı ve yedinci sınıf düzeylerinde eşit olarak dörder sınıf; sekizinci sınıf düzeyinde üç sınıf ve beşinci sınıf düzeyinde iki sınıf araştırma sürecinde gözlemlenmiștir. Tabloda, sınıfların öğrenci sayılarına ilişkin elde edilen verileri yer almaktadır. Görsel sanatlar dersinin yapısı, kuramsal ve uygulamalı içeriklerden oluştuğu için dersin planlanmasında öğrenci sayısı önemli bir belirleyici olarak ortaya çıkmaktadır. Devlet okulunda görsel sanatlar dersi öğrenci sayısının ortalama 28 kişilik olabileceği sonucu elde edilmiştir.

Görsel sanatlar dersinin, sınıf ya da atölye ortamında işlendiğine ilişkin veriler eklenmiştir. Buna göre iki ders atölye ortamında, 11 ders sınıf ortamında yapılmıştır. $\mathrm{Bu}$ veriler, görsel sanatlar dersinin \%85 oranında sınıf ortamında işlendiğini ortaya koymaktadır. Son olarak çalışma grubunda en az dört, en çok 32 yıl çalışmış ve farklı deneyimlere sahip olan öğretmenler araştırmaya katılmıştır. Çalışma grubu öğretmenlerinin meslek yıllarına göre çeşitlilik göstermesi, varolan durumun belirlenmesinde çalışmanın geçerliğini sağlamaktadır.

\section{Veri Toplama Araçları}

Temel nitel araştırma deseninde veriler; görüşme, gözlem ya da doküman analizi yoluyla toplanır. Hangi soruların sorulduğu, neyin gözlemlendiği, hangi dokümanların ilişkili kabul edildiği çalışmanın kuramsal çerçevesine bağlıdır (Merriam, çev. 2013).

Ortaokul görsel sanatlar ders sürecinin araştırılmasına ilişkin gözlem ve görüşme araçlarının oluşturulması için açık uçlu anket maddeleri hazırlanarak ön araştırma yapılmıştır. Görsel sanatlar öğretmenlerinin karşılaştıkları sorunları belirlemek için hazırlanan açık uçlu anket soruları çevrim içi ortamda yayımlanmıştır. Çevirim içi ortamda, on yedi görsel sanatlar öğretmeni tarafindan yanıtlanan sorular, veri toplama aracının hazırlanmasında katkı sağlamıştır. Aynı zamanda veri toplama aracının geliştirilmesinde www.gorselsanatlar.org internet sitesinde öğretmenlerin görüntüledikleri konular ve paylaşımlar incelenmiştir. 
Araştırmada yapılan ön hazırlık ve alanyazın araştırmasına dayalı olarak yarı yapılandırılmış gözlem formu ve yarı yapılandırılmış görüşme formu hazırlanmıştır. Veri toplama araçlarının uygulanabilirliğine yönelik olarak uzman görüşü alınmıştır. Ayrıca hazırlanan veri toplama araçlarının Bursa ve Ankara ilinde iki öğretmen belirlenerek pilot uygulamaları gerçekleştirilmiştir. Pilot uygulama sonunda gözlem ve görüşme formu düzenlenerek saha araştırmasına başlanmıştır.

Gözlem verilerinin toplanması. Görsel sanatlar dersi gözleminde, bir konunun başlangıcından itibaren gözlemlerin başlaması için öğretmenlerle önceden görüşülmüş ve tarihler belirlenmiştir. Ders gözlemlerinde, araştırmacı ses kayıt cihazı kullanmış ve Yapılandırılmış Görüşme Formu ile ders süresince derse giriş, tasarım, uygulama ve ölçme değerlendirme bölümlerine yönelik notlar alınmıştır. Öğretmen ve öğrencilere ses kayıt cihazı kullanma konusunda bilgilendirme yapılmıştır. Ders gözlemlerinde, ortaokulda haftada 40 dakika olan görsel sanatlar dersinde, bir konunun işlenmesi, üç ile beş hafta arasında değişmektedir. Glaser ve Strauss (1967) araştırma sorusunun yanıtı olabilecek kavramların ve süreçlerin tekrar etmeye başladığı aşamaya (doyum noktası) kadar veri toplamaya devam edilmesini gerektiren bir örnekleme yaklaşımına işaret eder (akt. Yıldırım ve Şimşek, 2008). Araştırmacı saha çalışmasında uzun süreli etkileşim içinde bulunarak, 13 öğretmenin dersini gözlemlemiştir. On üç öğretmenin dersinde yapılan toplam gözlem süresi 25 saat sürmüştür.

Görüşsme verilerinin toplaması. On üç görsel sanatlar öğretmeni ile bireysel ve yüz yüze görüşmeler yapılmıştır. Görüşme öncesinde öğretmenlere ses kayıt cihazı kullanma konusunda bilgilendirme yapılmıştır. Ayrıca Aydınlatılmış Onam Formu katılımcılara imzalatılmıştır. Araştırma kapsamında hazırlanan yarı yapılandırılmış görüşme formu kullanılarak altı soru öğretmenlere sorulmuştur. Öğretmenlerle yapılan görüşmelerin her biri yaklaşık 30 dakika sürmüş ve toplam 13 saat görüşme gerçekleştirilmiştir. Toplanan veriler incelendiğinde veri doygunluğuna ulaşıldığı için alan araştırmasının sonlandırılması uygun görülmüştür.

\section{Verilerin Analizi}

Verilerin çözümlenmesinde gözlem sürecinde alınan ses kayıtları deşifre edilmiştir. Ayrıca gözlem sırasında Yarı Yapılandırılmış Gözlem Formu ile alınan ham saha notları ile bir araya getirilmiştir. Diğer veri toplama aracı olan görüşme yönteminden elde edilen ses kayıtları da araştırmacı tarafından deşifre edilmiştir. Gözlem ve görüşme deşifreleri, doğruluğunun onaylanması için başka bir araştırmacı tarafından kontrol edilmiş, düzeltmeler yapılmıştır.

Araştırmada gözlem ve görüşme yöntemlerinin veri analizinde, deşifre edilen metinler içerik analizi aşamaları kullanılarak araştırma problemine ilişkin kavramlara ulaşılmıştır. "İçerik analizinde temel amaç, toplanan verileri açıklayabilecek, tümevarımcı bir analizle verilerden yola çıkarak kavramlara ve ilişkilere ulaşmaktır" (Yıldırım ve Şimşek, 2008, s. 242). Verilerin kodlanmasına, gözlem deşifre metninden başlanmıştır. Araştırmanın probleminden yola çıkarak görsel sanatlar dersinin gereksinimleri çerçevesinde deşifreler incelenmiş, notlar alınarak açık 
kodlama yapılmıştır. "Açık kodlama, deşifre edilmiş verilerde önemli fikir ve kavramların kodlarla işaretlenmesidir" (Christensen, Johnson ve Turner, çev. 2015, s. 421). Gözlem deşifrelerinin açık kodlama yapılmasının ardından uzman görüşü alınmıştır. Deşifreler tekrar okunarak açık kodların birbirleriyle ilişkili olanları kendi içinde gruplandırılmıştır. Yapılan gruplandırmayla beraber gözlem verilerine yönelik kategorilere ulaşılmıştır. "İkinci aşama olarak eksen kodlaması ile hangi kavramların daha önemli olduğuna karar verilir ve bunlar belirli bir düzene oturtulur" (Christensen ve diğ., çev. 2015, s. 421).

Verilerin analizinde diğer veri toplama aracı olan yarı yapılandırılmış görüşme formunun deşifreleri aynı şekilde incelenmiştir. Deşifreler, görüşme soruları dikkate alınarak incelenmiş ve ilgili olanlar açık kodlama ile belirlenmiştir. Gözlem ve görüşme verilerinden elde edilen kodlamalar birbiriyle karşılaştırılmış araştırma çerçevesinde ilişki kurularak gruplandırılmıştır. Verilerin analiz süreci, verinin yinelenen bazı örüntülerini kategoriler ve temalar altında toplamaktır. Kategoriler, verilerin doğrudan kendisi değil, verilerden çıkarılan kavramlardır (Merriam, çev. 2013). Verilerin çözümlenmesi sonucunda elde edilen araştırma bulguları, araştırma problemine yönelik olarak sınırlanmış alanyazın araştırması ışığında tartışılmıştır.

\section{Araştırmada Geçerlik ve Güvenirlik}

Nitel araştırma yönteminde, çalışılan konunun derinlemesine incelenmesi için çalışma grubunun belirlenmesinde çeşitlilik, farklılık ve aykırılıkların ortaya çıkarılması beklenir (Yıldırım ve Şimşek, 2008). Çalışma grubundaki öğretmenlerin meslek yıllarına göre çeşitlilik göstermesi, varolan durumun belirlenmesinde çalışmanın dış geçerliğini sağlamaktadır. Ayrıca çalışma grubunun farklı sosyoekonomik bölgelerde yer alan ortaokullardan seçilmesi nitel araştırmada kullanılan aktarılabilirlik kavramını sağlamaktadır. Nitel araştırmada, araştırma sonuçlarının benzer ortamlara aktarılabilirliğinin sağlanması, nicel araştırmada evrene yapılan genellemenin dış geçerlik olarak nitelendirilmesine karşılık gelmektedir.

Araştırmanın iç geçerliğinin arttırılmasında birden fazla veri toplama yönteminin kullanılması ile üçgenleme stratejisi kullanılmıştır. Değişik yöntemlerin birlikte kullanılması, toplanan verilerin ve açıklamaların güvenirliğinin ve geçerliğinin saptanmasında önemlidir (Yıldırım ve Şimşek, 2008). Araştırmada, görsel sanatlar dersinin varolan durumu, doküman incelemesi, gözlem ve görüşme yöntemiyle belirlenmiştir. Gözlem yoluyla toplanan veriler, yapılan görüşmelerle birlikte desteklenmiştir. Gözlem ve görüşme verilerinin kodlanması arasındaki tutarlık nitel araştırma alan uzmanı tarafından incelenmiştir. Ayrıca iç geçerliğin sağlanması amacıyla uzun süreli etkileşim sağlanmıştır. Gözlem ve görüşme yoluyla elde edilen bulgular yorum katılmadan doğrudan alıntılarla zenginleştirilerek sunulmuştur.

\section{Bulgular}

$\mathrm{Bu}$ bölümde, ortaokul görsel sanatlar dersinin öğrenme-öğretme sürecine yönelik olarak öğretmenlerin deneyimleri yer almaktadır. Görsel sanatlar dersi 
öğrenme-öğretme süreci araştırmanın alt amaçları doğrultusunda bulgular olarak sunulmuştur.

\section{Görsel Sanatlar Dersinde Kuramsal Bilginin Aktarılması}

Görsel Sanatlar dersinin kuramsal bölümüne yönelik araştırmanın alt amacı, disiplin odaklı sanat eğitimi yaklaşımının kullanımı (sanat tarihi, sanat eleştirisi, estetik ve uygulama çalışması), örnek görsellerden yararlanılması ve tasarım sürecine yer verilmesi kategorileri ile ele alınmıştır (Tablo 2).

Tablo 2

Görsel Sanatlar Dersinde Kuramsal Bilginin Aktarllmasina İlişkin Kategoriler Görsel Sanatlar Dersinin Kuramsal Bölümü Nasıl Gerçekleştirilmektedir?

a) Disiplin Odaklı Sanat Eğitimi Yaklaşımının Kullanımı (Sanat tarihi, sanat eleştirisi, estetik ve uygulama çalışması)

b) Örnek Görsellerden Yararlanılması

c) Tasarım Sürecine Yer Verilmesi

Görsel sanatlar dersinde kuramsal bilginin aktarılması ile ilgili ulaşılan kategoriler Tablo 2'de yer almaktadır. Bu kategorilere ilişkin bulgular aşağıda açıklanmaktadır.

Disiplin odaklı sanat eğitimi yaklaşımının kullanımı. Çalışma grubundaki 13 öğretmenin, öğrenme öğretme sürecinde kullandıkları yöntem ve tekniklere bakıldığında, dersin giriş kısmında anlatım ve soru-cevap yöntemini kullandığ 1 görülmektedir. Anlatım yönteminin kullanımında iki öğretmen, öğretim materyali olarak akıllı tahtayı kullanmıştır. Öğretmenlerin, disiplin odaklı sanat eğitimi yaklaşımına yönelik olarak derste sanat tarihi, sanat eleştirisi, estetik ve uygulama çalışması disiplinlerine nasıl yer verdikleri aşă̆ıda ele alınmıştır.

Sanat tarihi. Çalışma grubunda üç öğretmen dersin konusuna yönelik olarak sanat tarihi disiplinine yer vermiştir. Bu dersler ebru çalışması, amblem-logo çalışması ve mitoloji ders içerikleridir. Sanat tarihine ilişkin bilgilerin aktarımında anlatım yöntemi kullanılmıştır. Öğretim materyali olarak akıllı tahta ile sunum yapan iki öğretmen olduğu gözlemlenmiştir. Yapılan görüşmelerde "Sadece anlatmaya yönelik konular olduğu zaman inanılmaz bir kargaşa oluyor. Sanki bir matematik öğretmeninin hadi şimdi resim yapıyoruz demesi gibi kıyamet kopuyor." (BUR/Y1/K7) ifadesi ile öğrencilerin görsel sanatlar dersine yönelik algıları belirtilmiştir. $\mathrm{Bu}$ durum, öğretmenlerin sanat tarihi disiplinine yer vermemesini açıklayan değişkenlerden biri olarak kabul edilebilir. Ayrıca sanat tarihini daha ileri sınıf düzeylerinde verilmesi ile ilgili görüş belirtilmiştir. "Ara sıra sekizler (sınıf) malzeme getirmemişlerse ressamlarla ilgili bilgiler vermeye çalışıyorum." (ANK/M2/K13).

Görüşmelerde, görsel sanatlar öğretmenlerini kültürel miras öğrenme alanının (sanat tarihi disiplini) uygulanmasına yönelik olarak görüşleri şu şekildedir: "Kültürel 
mirasa falan girdiniz mi, çocuklar için pek bir şey ifade etmiyor. Hele bu yaş grubu, tamamen pop kültürüyle alakalı olduğu için bizim değerlerimiz aileden geliyorsa bir şey ifade ediyor.” (BUR/N2/K2). Ancak pop kültürü de günümüz kültürünü oluşturan bir öğe olarak ele alınabilir. Çağdaş sanat ve modern sanat müzeleri de günümüz kültürünün aktarılabileceği kaynaklardır. Ayrıca kültürel miras öğrenme alanına ilişkin kazanımların müze ortamlarında gerçekleştirilmesi ile ilgili sorun yaşadıklarını belirtmişlerdir. "Müzeler konusunda ben çok sıkıntı çekiyorum. Sanal ortamda müze gezdirebilirsiniz. Onun dışında çocukları müzeye zaten götüremem, mümkün değil." (BUR/Y1/K8).

Sanat eleştirisi. Araştırmada, gözlem yapılan sınıflarda sanat eleştirisi disiplinini kullanan öğretmen olmamıştır. Sanat tarihi disiplinine yer veren iki öğretmen konu anlatımı içerisinde "Mitoloji denince ne geliyor aklınıza, zümrüt-ü anka kuşunu bilenler var mı?" (ANK/E2/K11), "Ebruyu daha önce gördüğünüz kaynaklar, yerler var mı? Gördünüz mü renklerin güzelliğini?” (BUR/O1/K4) sorularıyla derse girişte dikkat çekmiştir. Öğretmenlerin derse girişte ele alınacak konuya ilişkin kavramın tanımını yaparak (örneğin, portre veya natürmort kavramının tanımı) uygulama çalışmasına geçtikleri görülmüştür. "Grafiti nedir, bilen var mı?" (BUR/O2/K6), "Günlük hayatımızda örüntüye bana kim örnek verebilir?" (BUR/N1/E1).

Yapılan görüşmelerde öğretmenler sanat eleştirisi disiplinine yer veremediklerini belirtmiş̧ir. "Sanat eleştirisine çok fazla giremiyoruz. Genellikle projeksiyonla ve konuşmayla geçen bir şey olduğu için çocukların ilgisi çok fazla olmuyor." (BUR/N1/E1). Ayrıca sanat eleştirisi disiplininin ortaokul düzeyine uygun olmadığı nedeniyle derste yer verilemediği belirtilmiştir. "Sanat eleştirisi, o kuramlar lise öğrencilerine yönelik. Yani bunlar daha bir lokmacık çocuk. Daha sanatın ne olduğunu çözmeye çalışırken sanat eleştirisi kuramlarını işin içine sokmak bir mucize beklemek olur." (ANK/E1/K10).

Estetik. Estetik disiplininde, sanat eserinin anlamı, kökeni ve değeri ele alınır. Sanatın farklı görüşlere, imgelere ve kültürel farklılıklara saygı duymayı öğreten yapısı kazandırılmaya çalışılır. Görsel Sanatlar Dersi Öğretim Programı estetik öğrenme alanında sanat eserinin duygu ve düşünceleri ifade etmedeki gücünü; ögrencilerin sanatın anlamı ve değeri konusunda bir yargıya varmaları; sanata ve sanatçıya saygı duymayı öğrenmeleri; sanat eserine yönelik düşüncelerin ve tercihlerin farklı olabileceğini görmeleri ve bu düşüncelere saygı duymayı öğrenmelerine ilişkin bilgi, beceri, duyuş kazanması hedeflenmiştir (MEB, 2018).

Çalışma grubu öğretmenleri derste planlı olarak estetik öğrenme alanına yer vermemiştir. Ancak dersin ilgili kısımlarında, öğrencilere sanata ve sanatçıya değer verilmesi gerektiğine ilişkin bilgilendirmelerde bulunmuştur.

Herkes ağaca bakar ama sanatçılar ağacın damarlarına bakar, renklerine bakar. ... Gözlem yaptığınız taktirde iyi bir sanatçı olursunuz. Gözlem yaptığınız taktirde mesleğinizin en iyisi olursunuz. ... Gerçekten iyi bir resim yapmak 
istiyorsanız gözlem yapmaktan vazgeçmeyin. Ama bunu ders için değil, normal hayatınızda da her şeyi gözlemleyin. (ANK/E1/K10)

Ayrıca sanatın kültürle olan ilişkisi ve farklı sanat dallarının olduğu, sanatın kendi içinde bir bütün olduğu da aktarılmıştır. "İnsanlar, kendi topraklarındaki bazı bulgularla, yaşadıkları olaylarla birçok eser verilmiş. Mitolojide, hem edebi eserler hem sanat eserleri verilmiş, pek çok mimari eser var, heykeller var, aynı zamanda resimler var." (ANK/E2/K11), "Çocuklar, sanatın her dalı birbiriyle etkileşim içindedir. Biz şimdi resim yapıyoruz ve müzik dinliyoruz." (ANK/M1/K12).

Uygulama çalışması. Çalışma grubunda tüm derslerde uygulama çalışmasına yer verilmiştir. Çalışma grubunda yer alan 13 görsel sanatlar öğretmeninin $10^{\prime} u$ derse doğrudan uygulama çalışması ile başlamıştır. Uygulama çalışmasında sekiz öğretmen gösterip yaptırma tekniğini kullanarak öğrencilere çalışmanın adımlarını açıklamıştır. Gösterip yaptırma tekniğinin uygulanmasında, beş ögretmen tahtaya çizerek anlatmış, üç öğretmen ise kullanılacak tekniği uygulamalı olarak göstermiştir. "Size kılavuz olacak önemli noktaları tahtaya çizerek anlatıyorum. Benim tahtada çizdiğimin sırasını karıştırmayacaksınız. Sırayla gideceksiniz doğru bir şekilde.” (BUR/N2/E3). Gösterip yaptırma tekniğinin kullanılmasında, öğretmenin yakınında olan öğrenci grubunun çalışmayı anladığı ancak arkadaki öğrencilerin uygulamanın adımlarını kavramakta zorluk yaşadığı sıklıkla gözlemlenmiştir. Uygulama adımlarının tüm sınıfa aktarılamamasından dolayı, sınıf yönetiminin sağlanmasında ve uygulama çalışmalarının tamamlanmasında aksaklıklar oluştuğu gözlemlenmiştir. Bu süreçle ilgili görüşme analizlerinde de öğretmen, "Öğrenciye dersi anlatmaya, göstermeye, uygulatmaya çalışırken daha hareketli, dikkat dağınıklığı yaşayan çocukları hakimiyetim altına almakta zorlanabiliyorum." (BUR/O1/K4) ifadesiyle gözlem bulgularını desteklemiş̧ir. Uygulama çalışması ile ilgili derinlemesine analiz bulguları ilerleyen kategorilerde incelenmiştir.

Örnek görsellerden yararlanılması. Görsel sanatlar öğretmeni derste örnek görselleri kullanarak öğrencilerin uygulama çalışması adımlarını kavramalarını, çalışmalarıyla ilgili düşünce geliştirmelerini ve beklenen çalışma sonucuna ilişkin bilgi edinmelerini amaçlamaktadır. Çalışma grubunda örnek görsellerden yararlanan yedi öğretmen bulunmaktadır. Öğretmenlerin ikisi daha önce yapılmış çalışmaları göstermiş; iki öğretmen çizim tekniği konusunda yardımcı doküman getirmiştir. Üç öğretmen ise Pinterest uygulamasını, Google görsellerini ve hazırladığı sunumu kullanmıştır. Öğretmenlerle yapılan görüşmelerde öğretmenlerin örnek görsellere nasıl ulaştıklarına yönelik ifadelerinde, kaynak olarak internet sitelerinden yararlandıklarını belirtmişlerdir. "Önceki yıllarda elimde sanat dergilerim olurdu, artık her şey akıllı telefonda.” (ANK/E1/K10). Aynı zamanda öğretim programının, nitelikli görseller ve çalışmalar yönünden desteklenmediği ve bu yüzden Pinterest uygulamasının sıklıkla kullanıldığı da belirtilmiştir. "Müfredat beni görsel yönden zenginleştiremiyordu. Pinterest bizi kurtaran, oradan aldığımız çok çalışma vardır." (ANK/Ç1/K9) ifadesiyle kitap yerine internet sitelerinden daha fazla yararlanıldı̆̆ 1 ortaya çıkmıştır. 
Derste örnek gösterimi konusunda öğretmenlerin temkinli davrandıklarına gözlem ve görüşme analizlerinden ulaşılmıştır. Öğretmenler, hiç örnek göstermemeyi, kısa süreli görselden yararlanmayı veya uygulama sürecinde görselleri kapatmayı tercih etmektedirler. Öğretmen "Yapacağınız resimlerde biraz kendi hayal gücünüzü oluşturun. Görselleri kapatabilir misin Ahmet?" (ANK/E2/K11) ifadesiyle öğrencilerin hayal güçlerini ortaya çıkarmasında etkilenmemeleri için görsellerin kapatılmasını istemiştir. Natürmort dersinde öğretmen "Ben tahtaya çizmek istemiyorum. Çünkü tahtadakinin aynısını taklit edip deftere çiziyorlar." (BUR/Y1/K7) açıklamasıyla örnek görsellerin gösteriminde temkinli davrandığını belirtmiştir. Öğretmenlerle yapılan görüşmelerde de örnek görsellerden yararlanma konusunda benzer tutuma sahip oldukları ortaya çıkmaktadır. "Örnek çalışmayı gösterdiğimde çok etkileniyorlar ve aynısını yapmaya çalışıyorlar.” (BUR/Y1/K8). Öğretmenler, örnek görsel göstermenin öğrencilerin çalışmaları hakkında düşünce geliştirmelerine katkı sağlamadığını deneyimlemiş olabilirler. Amblem ve logo tasarımı yapılan derste belirtildiği gibi öğrenciler örnek görsellerin aynısını çizme eğilimindedir. "Öğrenci: Hocam tahtadakilerini çizsek olmuyor mu? Öğretmen: Hayır tahtadakiler örnek.” (BUR/O2/K5). Öğrencinin bireysel fikrinin geliştirmesinde, örnek gösteriminin tek başına yeterli olmadığı, tasarım sürecinin geliştirilmesine yönelik içeriklerin oluşturulmasına gereksinim olduğu sonucuna ulaşılabilir.

Tasarım sürecine yer verilmesi. Tasarım süreci, öğrencilerin uygulama çalışması öncesinde düşünsel ve çizgisel planlama süreci olarak tanımlanabilir. Tasarım sürecinin etkililiği, kuram ve uygulama bağlamının kurulması, uygulama çalışmasının nitelikli ilerlemesi ve sonuçlanması ile doğru orantılıdır. Bu nedenle uygulama çalışması sürecinden önce ele alınmıştır. Çalışma grubunu oluşturan 13 görsel sanatlar öğretmeninden ikisi, öğrencileri tasarım yapmaları konusunda yönlendirmiştir.

Mitoloji dersinde öğretmen önceden mitoloji konusunda araştırma yapmalarını istemiştir. Sınıf içinde öğrenciler etkilendikleri mitoloji kahramanı ve öyküsünü anlatmıştır. Yerli ve yabancı mitolojik öykülerle ilgili düşünceler konuşulduktan sonra tasarım sürecine geçilmiştir.

Resmin tamamını planla, gerekirse küçük bir kağıt üzerinde, deneme çizimlerini yap. O deneme çizimlerinden sonra defterine geç. Çünkü bazen dik tutman gerekecek, bazen yatay tutman gerekecek, artı kompozisyon çok önemli, onu sığdırıp sığdıramayacağını belirlemen, o yüzden deneme çizimini yap defterinde ondan sonra çalışmaya başla. Onu buraya çizeyim, onu şuraya çizeyim ile resim tamamlanır mı? Tamamlanmaz. Lütfen önceden tasarlayıp ondan sonra yapmanızı istiyorum. (ANK/E2/K11)

İkinci öğretmen amblem ve logo konusunda uygulama çalışmasından önce, ön hazırlık yapılmasını istemiştir. "Önce bir A4 kâğıdında çalışabilirsiniz. Birinci adım, firmanızın ne firması olduğuna karar vereceğiz. İkincisi firmanızın ismine karar verin. Üçüncü adım, belirlediğiniz isme göre onun amblem ve logosunu tasarliyoruz." (BUR/O2/K5). 
Tasarım sürecine yer vermeyen öğretmenlerin bu konudaki tutumları, herhangi bir yönlendirme yapmadan öğrencilerin kendi yollarını bulmalarını sağlama yönündedir. Öğrencinin etkilenmemesi için tasarım sürecine isteyerek yer vermedikleri belirtilmiştir. "Ben tasarım konusunda asla karışmam. Yöntemi, yolu gösteriyorum, fikir veriyorum, onun dışında serbest bırakıyorum. Kendi işleri için kendi karar verecek." (ANK/M1/K12). Sınıf içinde de öğretmenler tasarım sürecinde benzer anlayışla öğrencilere müdahale etmemeyi seçmişlerdir. "Yani size kalmış buna ben karışmıyorum. Hayır fikir sizden, siz tasarlayacaksınız. ... Birim tasarlıyoruz. Bu birim sizin zekânıza, sizin yaratıcılığınıza kalmış." (BUR/N1/E1) ifadesi ile tasarım süreci öğrencinin üstesinden gelmesi beklenen bir süreç olarak ele alınmıştır.

Mozaik çalışmasının yapıldığı derste (Şekil 1), öğrenciler bu durumun sonucu olarak çalışmalarda benzerlik oluştuğunu fark etmiştir. "Hocam, ben vazo yapacağım, o da vazo yapıyor. Öğretmen: Senin hayalindeki vazo ile arkadaşının hayalindeki vazo farklıdır." (BUR/Y1/K8).

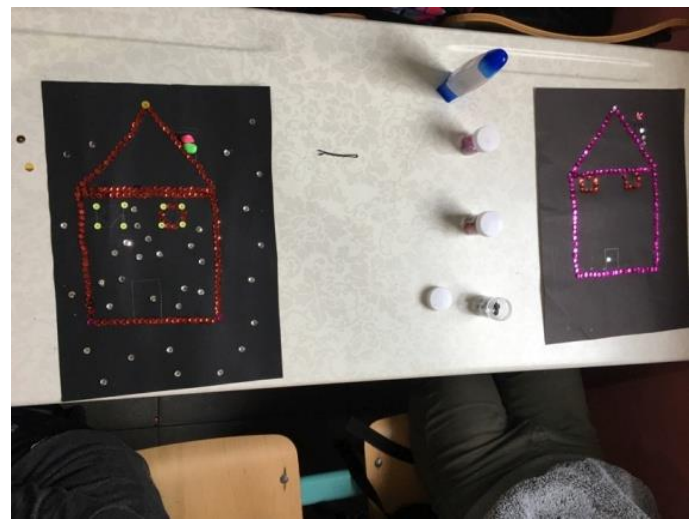

Şekil 1. Mozaik çalışması.

Diğer taraftan teknik beceri, el işi ve görme eğitimini amaçlayan içeriklerde tasarım sürecine yer verilmediği gözlemlenmiştir. Portre çalışması yapılan derste, "Virgül gibi burun, ters virgül gibi yapacaksın." (ANK/Ç1/K9) "Öğretmen: Evet kime çizeyim başka? Bir tane örnek yaptım ya, siz devamını çoğaltın.” (ANK/E1/K10) ifadelerinde olduğu gibi verilen yönergenin birebir uygulanması hedeflenmektedir. Böylece öğrencilerin çalışmalarının birbirine benzemesi ya da öğretmenin gösterdiği örneğe benzetmeye çalışılması sonucu ortaya çıkmaktadır. Farklı bir görüş olarak teknik beceri gerektiren çalışmaların özellikle tercih edildiği belirtilmiştir. "Şimdi 30 öğrencinin otuzunun da yetenekli olmasını bekleyemezsin. Dolayısıyla daha teknik işler yaptırıyorum ben.” (ANK/M1/K12).

Tasarım sürecinin, öğrencilerin düşünsel ve çizgisel planlama yapması, bireyselliğinin ve uygulama çalışmasının niteliğinin ortaya konulması ile doğru 
orantılı olmasına karşın mevcut durumda öğretmenler tarafından farklı değerlendirilmiştir. Öğrencilerin yaratıcılıklarını kendiliğinden ortaya koymaları beklenmektedir. Ayrıca tasarım süreci gerektirmeyen teknik beceri, el işi ya da görme eğitimini amaçlayan içerikler seçerek yetenek kavramının dışarıda bırakılmaya çalışıldığı söylenebilir. Böylece görsel sanatlar dersinin daha sınırlayıcı bir anlayışla ilerlediği sonucu ortaya çıkmaktadır.

\section{Görsel Sanatlar Dersinde Uygulama Çalışması Süreci}

Görsel sanatlar dersinin uygulama çalışması bölümüne yönelik araştırmanın alt amacı, uygulama çalışmasında konu belirlenmesi, öğretmenin uygulama sürecinde esnek olması, uygulama çalışmasının öğrenci düzeyine uygunluğu, dersin planlanan süreye uygunluğu kategorileri ile ele alınmıştır (Tablo 3).

Tablo 3

Görsel Sanatlar Dersi Uygulama Çalışması Sürecine İlişkin Kategoriler Görsel Sanatlar Dersinde Uygulama Çalışması Süreci Nasıl Gerçekleştirilmektedir?

a) Uygulama Çalışmasında Konu Belirlenmesi

b) Öğretmenin Uygulama Sürecinde Esnek Olmas1

c) Uygulama Çalışmasının Öğrenci Düzeyine Uygunluğu

ç) Dersin Planlanan Süreye Uygunluğu

Görsel sanatlar dersinde yapılan uygulama çalışması süreci ile ilgili ulaşılan kategoriler Tablo 3'te yer almaktadır. Bu kategorilere ilişkin bulgular aşağıda açıklanmaktadır.

Uygulama çalışmasında konu belirlenmesi. Görsel sanatlar öğretmenleri uygulama çalışması içeriğinin belirlenmesinde, sınıf düzeyini dikkate aldıklarını görüşmelerde belirtmişlerdir. "Beşinci sınıflar ilkokuldan geldikleri için biraz daha onlara çocuksu, eğlenecek, deşarj olacak işler yaptırıyorum. Sekizlere onların yaşına uygun sanatsal içerikli çalışmalar yaptırıyorum." (ANK/E1/K10) ifadesi ile ders içeriği hakkında bilgi vermiştir. Bir diğer öğretmen ise "Beşinci ve altıncı sınıflarda alışmaları için karakalem ağırlıklı çalıştırırım. Yedide ve sekizde daha çok renk kullanıyorum." (BUR/Y1/K7) ifadesi ile resim tekniklerinin sınıf düzeylerine dağılımı konusunda görüşlerini belirtmiştir. Ders içeriğinin belirlenmesi ile ilgili iki görüş arasında farklı bakış açıları bulunmaktadır. Araştırmanın demografik özelliklerine meslek yılı açısından bakıldığında (Tablo 1), ilk öğretmenin 19 yıl, diğer öğretmenin altı yıl deneyiminin olduğu görülmektedir. Ders içeriğinin belirlenmesinde, ilk öğretmenin meslek y1lı içinde öğrencinin düzeyine uygun çalışmaları deneyimlediği, ikinci öğretmenin karakalemden renge doğru gelişen, lisans programında gördüğü atölye dersleri anlayışını benimsediği söylenebilir. Görsel sanatlar öğretmenlerinin ders içeriğini belirlemedeki tutumunun zaman içinde farklılaştı̆̆ı sonucuna varabiliriz. 
Öğretmenliğin ilk yıllarından sonra yaş ilerledikçe ve kıdem arttıkça çok değişiyor öğrenciye yaklaşımınız, tarzınız. Yıllar sonra eski öğrencilerimle karşılaştığımda; öğrencilerimden özür diliyorum. Sizi ne kadar zorlamışım, idealist bir şekilde şunu da çizdireceğim, bunu da yaptıracağım. Not verirken prosedüre uygun şekilde puanlamalar... Şimdi çok daha rahatım. (ANK/E2/K11)

Aynı zamanda ders süresi, malzemenin sağlanması gibi fiziksel koşulların uygulama çalışması içeriğinin belirlenmesinde önemli olduğu öğretmenler tarafindan belirtilmiştir. "SInıf ortamında rahatlıkla işleyebileceğimizi düşündüğümüz yani çok malzeme gerektirmeyen konular seçmeye çalışıyoruz." (BUR/O2/K5), "Burası Güzel Sanatlar Lisesi değil, akademi değil. Öğrencilerin imkânları kısıtll, ders 40 dakika, 40 dakikada neler yapılabilir, hep onu düşünüyoruz." (ANK/M1/K12).

Öğretmenin uygulama sürecinde esnek olması. Görsel sanatlar dersinde, öğrencinin yaptığı çalışmaya yorumunu ve bireyselliğini katabilmesi için, uygulama sürecinin esnek olması, kararlarını verebileceği seçenekler sunulması önemlidir. Araştırmada, öğretmenlerin uygulama çalışmasında izlenecek adımları kontrollü biçimde öğrencilere aktardıkları görülmüştür. Tüm öğrencilerin aynı adımları izlemeleri ve aynı hızda tamamlamaları beklenmektedir.

Benim yaptığımın, benim tahtada çizdiğimin sırasını karıştırmayacaksınız. Sırayla gideceksiniz doğru bir şekilde. ... Buradaki en önemli nokta, kağıdı dörde bölerken dört çizginin tek nokta üstünden geçmiş olması lazım. Daha sonra daire şablonu kullanarak, bu çizgilere teğet değecek bir çember çiz. (BUR/N2/E3)

Bunun yanında sınıf düzeyi, konu, kâğıt boyutu ve renkli resim tekniğinin seçimi açısından bazı öğretmenlerin daha sınırlayıcı oldukları gözlemlenmiştir. Linol baskı dersinde "Hocam, başka renk yapabilir miyiz? Öğretmen: Hayır tek renk çalışacağız. ... Sen siyahla çalış, başka renk değil.” (ANK/M1/K12) yönlendirmesiyle öğrencilere renk seçimi konusunda sınırlamaktadır. Beşinci sınıfta geometrik şekillerle yapılan kompozisyonda, "Kuru boyada önemli olan bastıracaksın, kâğıt rengi altta gözükmeyecek.” (BUR/N2/E3) ifadesi ile 35x50 resim kağıdı üzerinde kuru boya tekniğinin kullanılması ve tamamen kapatıcı bir görünüm elde edilmesi istenmiştir.

Uygulama çalışmasında öğrencilerin istedikleri renkli resim tekniğini kullandıkları dersler gözlemlenmiştir. Çalışma grubu öğretmenlerinden üç öğretmen uygulama çalışmasında farklı renkli resim tekniği kullanmıştır. "Evet guaş boya, sulu boya, pastel boya kullanabilirsiniz. ... Çizimlerinizde küçük ayrıntılar var, buralarda kuru kalem kullanabilirsiniz." (ANK/E2/K11), "Sulu boyayla kuru boyayı karıştırdık burada. Pastel boya çalışmalarının arkasını hep sulu boyayla boyattııırım." (BUR/O2/K6).

Mevcut durum incelendiğinde, uygulama adımlarının yapılandırılmış olması ve uygulama tekniği konusunda öğretmenlerin tutumu, öğrencilerin bireyselliklerini 
ortaya koymalarını etkilemektedir. Bu durumun nedeni olarak öğretmenlerin sınıf kontrolünü sağlamak için sınırlayıcı bir tutum sergilediği düşünülebilir.

Uygulama çalışmasının öğrenci düzeyine uygunluğu. Gözlem analizlerinde uygulama çalı̧̧ması sırasında öğrencilerin gösterdikleri davranış biçimleri belirlenerek içeriğin öğrencinin düzeyinin üzerinde olması ile ilişkilendirilmiş̧ir. Uygulama çalışması sınıf düzeyinin üzerinde olduğunda, öğrencilerde resim yapma kaygısının artığı gözlenmiştir. Amblem ve logo tasarımı yapılan derste "Hocam ne amblemi, ne tasarımı. Of hocam bir daha anlatın." (BUR/O2/K5) ifadesi öğrencinin verilen konunun üstesinden gelemediğini göstermektedir. Portre çalışmasının yapıldığı sınıfta "Hocam beyaz kağıt bana bakıyor, ben ona bakıyorum. ... Ama hocam ben nasıl yapayım. Bana bir resim çizenin kırk yıl kölesi olurum." (BUR/Y1/K7) ifadeleriyle öğrencilerin resim yapma kaygısının arttığı gözlenmiştir.

Öğrencilerin resim yapma kaygısının üstesinden gelmek için arkadaşı ile birlikte çalışma, öğretmene bağımlılık duyma veya çalışmayı tamamlamama davranışlarını geliştirdikleri gözlenmiştir. "Öğrenci: Hocam bu ortak çalışmamız olur mu?" (ANK/Ç1/K9), "Hocam, iki kişi mi bu projeye girecek? Hocam, herkes ayrı ayrı mı yapacak?” (BUR/N1/E1) ifadeleriyle öğrenci akran desteğine gereksinim duyduğunu belirtmiştir. Öğretmenler ders sürecinde akran desteğinden ya da grup çalışmasından yararlanarak öğrenme-öğretme sürecinin niteliğini artırabilirler.

Öğrencinin resim yapma kaygısının üstesinden gelmek için kullandığı diğer yol öğretmene bağımlılık duymasıdır. "Öğretmen: Deniz beni niye bekliyorsun? Öğrenci (Deniz): Şey boyamayı yapmak için.” (BUR/O2/K6) ifadesinde öğrenci ilerlemek için öğretmeni beklemektedir. Portre yapılan sinıfta öğrenciler, "Hocam bana kulak yapar mısınız? Hocam burun çizemiyorum. Nasıl yapacağım? Hocam bize kafa çizecektiniz." (ANK/Ç1/K9) gibi sıklıkla öğretmenden yardım istemiştir. "Öğrenci: Hocam bana küçük bir oyuncak çizer misiniz?" (BUR/O2/K5) ifadesiyle benzer şekilde öğrenci uygulama adımlarının gerçekleştirilmesinde öğretmene gerek duymaktadır. "Öğrenci: Hocam ama çok zor onu yapmak. Öğretmen: Beraber yapın. Öğrenci: Hocam sizde yetenek var." (ANK/E2/K11) ifadesinde öğretmen akran desteğine yönlendirmesine rağmen öğrenci öğretmenin bilgisini tercih etmektedir. Uygulama sürecinde, gerçekçi çalışmalarla öğrenci düzeyinin göz ardı edilmesinin, öğrencinin onaylanma isteğini ve öğretmene olan gereksinimi artırdığı söylenebilir.

Dersin planlanan süreye uygunluğu. Araştırma gözlemlerinde, planlanan süre sonunda sınıftaki tüm öğrencilerin uygulama çalışmasını tamamlayabildiği bir ders bulunmamaktadır. $\mathrm{Bu}$ durumda öğretmenler, dersi bir hafta daha uzatmayı, tamamlamayanlar olsa bile yeni konuya geçmeyi veya ödev vermeyi tercih etmiştir. "Üç haftadır halen çizim aşamasındasınız. Haftaya not vereceğim." (ANK/E2/K11), "Dört dakika mı var? Yine geç kaldık. Yine yetişmedi." (BUR/N1/E1). "Çocuklar haftaya sınıfin yüzde yetmişi, yani buradaki yaklaşık 20 kişi bitirdiyse, yeni konuya geçeceğiz. Eğer yüzde yetmiş yani 20 kişiden az ise bir hafta daha uzatacağız." (BUR/N2/E3). 
Görsel sanatlar dersinde konu sonunda, sınıf içinde çalışan farklı grupların olduğu gözlemlenmiştir. "Bitiren arkadaşlarımız dersi boş geçirmesinler. Şu kâğıtlardan vereceğim kuru boya ve keçeli kalem kullanarak buraları renklendirerek süslüyorsunuz.” (BUR/O2/K5). Aynı derste öğretmen, yeni konuya başlayan öğrencilerin önceki çalışmalarını değerlendirmiştir. "Siz yeni çalışmaya başladığınızda da ben bu yaptığımız çalışmalarınıza not vereceğim.” (BUR/O2/K5). Son olarak daha önceki çalışmanın da tamamlanması istenmiştir. "Ayrıca natürmort çalışması birçoğunuzda yarımmış. Akı1lı tahtadan bakarak eksiği olanlar tamamlasın." (BUR/O2/K5). Bu derste öğrenciler de öğretmen de üç ayrı konuyu birlikte sürdürmektedir. Bu derste olduğu gibi öğretmenlerin dersini planlanan süre sonunda tamamlanması ile ilgili oldukça çaba sarf ettikleri görülmektedir. Görüşme analizlerinde de öğretmenlerin süre ve planlama konusunda zorlandıkları sonucuna ulaşılmıştır. "Bitiren de var, yolun başında olan da var. Neden böyle oluyor, anlamiyorum?" (BUR/N2/E3).

Görsel sanatlar dersinde planlanan süre sonunda uygulama çalışmasının tamamlanmaması durumu, ödev verme gerekliliğini ortaya çıkarmaktadır. Araştırmada dört öğretmen öğrencilerin uygulama çalışmasına devam etmeleri için ödev vermiştir. "Efendim, üç hafta dedik. Şimdi sizin ailelerinizden de şikâyet geliyor. Eve ödev vermiyoruz ama siz burada zamanı verimli kullanmadığınız için eve kalıyor o zaman iş." (BUR/N2/E3), "Öğrenci: Hocam bir şey soracağım biz bunları evde yapıp mı keseceğiz? Öğretmen: Evet.” (BUR/N1/E1), "Keşke şu tüyleri evde de biraz kesip hazırlasaydınız. Burada en azından direkt yapıştııı bitirirdik.” (ANK/E1/K10).

Araştırmada yedi öğretmen ödev vermek konusunda herhangi bir uyarıda bulunmadan yeni konuya geçmiştir. Dönem sonu yapılacak olan değerlendirmeye kadar öğrencilerin uygulama çalışmasını tamamlaması gerekmektedir. "Bu konuya devam eder, haftaya yeni konuya geçeriz." (ANK/E2/K11). Araştırmada iki öğretmen ise aksine çalışmaların sınıfta tamamlanmasını, ödev olarak yapılmamasını özellikle belirtmiştir. "Önümüzdeki haftada devam edip bitiriyoruz. Evde bir şey yapmıyoruz. Anlaşıldı mı? Evde sakın bir şey yapmayın. Çünkü çok zor ve uzun zaman alan bir çalışma değil." (BUR/Y1/K8), "Aynen, yani mesela bu üç haftada, üç ayrı çalışma eve ödev vermiyorum. Benim sistemim bu, 20 senedir hiç değiştirmedim." (ANK/M1/K12).

\section{Görsel Sanatlar Dersinde Ölçme ve Değerlendirme}

Görsel sanatlar dersinin ölçme ve değerlendirme kısmına yönelik araştırmanın alt amacı, ölçme-değerlendirme sürecinin planlanması, konu sonunda değerlendirme yapılması kategorileri ile ele alınmıştır (Tablo 4). 
Tablo 4

Görsel Sanatlar Dersi Ölçme ve Değerlendirme Sürecine İlişkin Kategoriler Görsel Sanatlar dersinde ölçme ve değerlendirme süreci nasıl gerçekleştirilmektedir?

a) Ölçme ve değerlendirme sürecinin planlanması.

b) Konu sonunda değerlendirme yapılması.

Görsel sanatlar dersinin ölçme ve değerlendirme süreci ile ilgili ulaşılan kategoriler Tablo 4'te yer almaktadır. Bu kategorilere ilişkin bulgular aşağıda açıklanmaktadır.

Ölçme ve değerlendirme sürecinin planlanması. Görsel sanatlar dersinde dönem içinde ürün dosyası ve sınıf içi performans durumlarına göre değerlendirme yapıldığı belirtilmiştir. "Toplamda dört not vereceğiz, bu dönemde. Bu dört notun ikisi ürün dosyası, diğer ikisi de ders içi performans notu." (ANK/M1/K12), "Üç not veriyorum, iki ders içi etkinlik, bir tane de ürün dosyası notu." (BUR/N1/E1). Öğretmenlerin ürün dosyası olarak belirttikleri, öğrencilerin dönem içinde yaptıkları çalışmaların tümünün getirilmesi olarak belirtilmiştir. Daha sonra bu çalışmalar sergi için kullanılmaktadır. "Ürün dosyasına öğrenciler, en beğendiği çalışmaları getirip bana teslim ediyorlar, ben dosya yapıyorum. Aynı zamanda sergiye koyuyoruz." (BUR/N1/E1). Sınıf için performans olarak öğrencilerin ders içinde çalışma süreçleri ele alınmaktadır. "Ders içi notlarınıza yansıyacak devam edin, konuşmaya." "Bakın performans notlarınızı ders içindeki davranışlarınıza göre vereceğim. Burada emek harcayan, emek veren insanla, konuşan malzemesiz oturan, koşan kişinin notu aynı olmayacak.” (ANK/E1/K10). Ayrıca sınıf içi değerlendirme olarak kontrol listesi ile öğrencilerin malzemelerinin kontrol edildiği belirtilmiştir. "Değerlendirmeyi art1, eksi, yıldız olarak değerlendiriyorum. Malzemesini getirenlere artı, getirmeyenler eksi, çok başarılı bulduğum sergi için ayıracağım resimlere yıldız veriyorum." (ANK/M1/K12).

Konu sonunda değerlendirme yapılması. Görsel sanatlar öğretmenleriyle yapılan görüşmede, süre yetersizliği, öğrenci sayısının fazlalığı, değerlendirecek çok fazla çalışma olması gibi nedenler yüzünden konu sonunda ölçme ve değerlendirme sürecinin aksadığı belirtilmiştir. "Tek ders, 26 tane sınıfa giriyorum, uygulama çalışmalarını ayrı ayrı değerlendirecek olursak, bu hem büyük bir kâğıt israfı hem de bize büyük eziyet." (BUR/Y1/K7), "Dersimiz 40 dakika olduğu için her dersin sonucunda değerlendirme yaparsak konu işleyemeyeceğiz. Onun için üç ya da dört resim bitirdiğimizden sonra not veriyoruz." (BUR/N2/E3). Öğretmenlerin birkaç konu işledikten sonra uygulama çalışmalarını değerlendirmeleri araştırma gözlemleriyle de desteklenmektedir.

Görsel Sanatlar dersinde, konu sonunda değerlendirme yapılması için ayrı bir zaman tanınmadığı gözlemlenmiştir. Öğrenciler yeni bir uygulama çalışmasına başladıktan sonra eş zamanlı olarak önceki çalışmanın değerlendirilmesine devam edilmiştir. "Evet şimdi yeni konuya geçelim ondan sonra mitoloji ile ilgili yaptığınız resimlerinizi değerlendirelim.” (ANK/E2/K11), "Siz yeni çalışmaya başladığınızda 
ben bu yaptığımız çalışmalarınıza not vereceğim.” (BUR/O2/K5). Diğer taraftan sınıftaki tüm öğrencilerin uygulama çalışmasını tamamlamaması nedeniyle değerlendirmenin ertelendiği gözlemlenmiştir. "Haftaya bir dakikalık bir dersi bile uzatmam. Haftaya yapan 100'ünü alır. Yapmayan da bir alır, bitti son hafta son.” (ANK/E1/K10), "Haftaya not vereceğim çünkü hâlâ tamamlamayanlar var. Şimdi not versem düşük alacaksınız." (ANK/E2/K11).

Çalışma grubunda iki öğretmen, konu sonunda uygulama çalışmasına yönelik değerlendirme yapmıştır. Öğretmen amblem ve logo uygulama çalışmasını, zamanında tamamlama, çalışmanın konuya uygunluğu, doğru boya kullanımı ve özgünlük ölçütlerine göre artı-eksi ile değerlendirmiştir. Portre çalışmasının işlendiği sınıfta öğretmen çalışmaları tamamlayan tüm öğrencilere 100 puan vermiş; diğer öğrencilere çalışmalarını tamamlamaları için zaman tanımıştır.

Öğretmenler, ölçme ve değerlendirme sürecinde öğrencilerin uygulama çalışmasını tamamlamasına ve öz düzenleme becerilerini sağlamasına dikkat etmektedir. "Sorumluluğunu bilen emek sarf eden herkes benden yüzünü alıyor." (ANK/E1/K10). Yapılan gözlem ve görüşme sonuçlarında öğretmenler benzer ifadelerde bulunmuştur. Bir öğretmen şu şekilde görüşlerini belirtmiştir: "Biz burada iyi işten ziyade tamamlanmış işe bakıyoruz. İşte malzemesini getirmiş mi, zamanında çalışmasını bitirmiş mi, sınıf içerisinde düzene uymuş mu, çalışmasını tamamladıktan sonra etrafını temiz bırakmış mı, gibi kriterler var. Yani daha basit şeyler ortaokul öğrencilerine yönelik.” (BUR/O1/K4). Ayrıca öğretmenler derse olan ilginin sürdürülebilmesi için ölçme ve değerlendirme sürecinde öğrencileri desteklemektedir. "Şu an çalışmayı tamamladı 100 puanı aldılar benden." (ANK/Ç1/K9), "Süper, kutluyorum ... hem estetik bakış açısına sahipsin hem düzenli, titiz. Aferin sana 100 üzerinden 100." (ANK/E1/K10), "Onu mutlu edecek, motive edecek, güzel notlar veriyorum. Hiç yapmayan öğrenciye zayıf veriyorum.” (BUR/O2/K6). Mamur (2004) çalışmasında, öğretmen ve öğrencilerin, görsel sanatlar dersinde yapılan sanatsal çalışmaların, öğrencinin derse karşı sorumluluğu, ilgi ve isteği ile gösterdiği pozitif çaba konusunda değerlendirilmesini savunduğu belirtmiştir.

\section{Tartışma, Sonuç ve Öneriler}

Ortaokul görsel sanatlar dersi öğrenme-öğretme süreci araştırılmış ve araştırmanın sonuçları alt amaçlara yönelik kategorilerle ortaya konulmuştur. Araştırmanın birinci alt amacı dersin kuramsal bölümünün nasıl gerçekleştirildiğidir. Öğretmenler dersin kuramsal bölümünde sanat tarihi disiplinine yer vermediklerini, bunun nedeni olarak görsel sanatlar dersinde anlatım içeren konuları öğrencilerin istememesi olarak belirtmiştir. Sanat eleştirisi ve estetik disiplinlerin öğrencinin ilgisini çekmediği ayrıca sınıf düzeyine göre bu disiplinlerin derste nasıl planlanacağı konusunda eksikliklerin olduğu belirtilmiştir. Öğretmenlerin ağırlıklı olarak uygulama çalışması disiplini ile derslerini yapılandırdığı ortaya çıkmaktadır. Özsoy (2007) görsel sanatlar eğitiminde, sanat tarihi, sanat eleştirisi, estetik ve uygulamadan oluşan dört sanat disiplini ile çalışılması gerektiğini belirtmiştir. Görsel Sanatlar Öğretim Programı da üç öğrenme alanı ve ilgili kazanımların dersin işlenişinde 
birbirleriyle ilişkilendirilmesi ifadesine yer vermiştir (MEB, 2018). Derste kullanılan öğretim yöntem ve teknikleri incelendiğinde, gösterip yaptırma tekniğinin kullanımında öğretmenlerin tüm sınıfa ulaşamadıkları sıklıkla gözlemlenmiştir. Tüm öğrencilere ulaşabilmek ve zamanı daha iyi kullanmak için, kamera ile görüntünün akıllı tahtaya yansıtılması veya ders öncesinde video hazırlanması gibi öğretim teknolojilerinden yararlanılabilir.

Dersin kuramsal bölümünde öğretmenlerin örnek görsellerden yararlanırken oldukça temkinli olmaları ve görselleri kapatmaları, alanyazın açısından farklı bir bulgu olduğu düşünülmektedir. Örnek görsellerden yararlanmanın, çeşitli düşüncelerin oluşması ve geliştirilmesine katk1 sağlayacağı düşünülürken öğrencilerin örneklere bağlı kalmasına ve düşünce üretmemesine neden olmuştur. Kırışoğlu (2005), öğrencinin konu ile ilgili değerleri oluşturması ve sorunu çözmesi için, örneklerden, önceki sanatçılardan, doğadan ve her türlü görsel kaynaktan yararlanılabileceğini belirtmiştir. Korkutal (2010), sanat eğitiminde biyolojik olarak görme ile başlayan sürecin, bilişsel bir etkinliğe çevrilmesi ve yeniden yorumlanarak kâğıt ya da tuval üzerine aktarılmasını açıklar. Alg1 bilgiye, bilgi yaratıcılığa, yaratıcılık uygulama çalışmasına dönüşür. Bu nedenle derste örnek görsel gösterme süreci, düşünce ve tasarımın geliştirilmesine katkı sağlayacak, bilginin yaratıcılığa dönüştürülmesini hedefleyen içeriklerle hazırlanabilir.

Öğrencilerin düşünsel ve çizgisel planlama yapmasını sağlayan tasarım sürecinde öğretmenler, öğrencinin yaratıcılığını kendiliğinden ortaya koymasını beklemektedir. Ayrıca teknik beceri, el işi ya da görme eğitimini amaçlayan konuların, tasarım ve bireysel ifadenin oluşmasını engellediği söylenebilir. Teknik bilginin aktarıldığ 1 derslerde, belli komutların sırayla işlendiği sınırlı ve geleneksel bir bakış açısı benimsenmiştir. Gude (2007) öğrencinin, sadece materyal ile uğraşmayı değil aynı zamanda düşüncelerle de uğraşmayı öğrenmesi gerektiğini belirtmiştir. Derste düşünsel ve çizgisel planlamanın göz ardı edilmesi, her öğrencinin aynı adımları sıkı bir şekilde gerçekleştirdiği uygulama çalışması sürecine neden olmuştur. Sınıf kontrolünün sağlanması amacıyla tüm öğrencilerin aynı adımları izlemeleri, belirli bir teknik ve sıra ile sonuca ulaşmaları beklenmektedir. Ancak Yılmaz (2017), öğrencinin başarı inancının oluşmasında seçimlerin etkili olduğu sonucuna ulaşmıştır. Sanat etkinliklerinde tek bir içerik ve tek bir teknik yerine; içerik ve teknikte çeşitliliğin sağlanması, öğrencilerin seçimlerine uygun öğrenme ortamlarının hazırlanması gerektiğini belirtmiştir.

Araştırmanın ikinci alt amacı, öğretmenlerin uygulama çalışması sürecini nasıl gerçekleştirdikleridir. Öğretmenler, uygulama çalışması içeriğinin belirlenmesinde zaman içerisinde, deneyimlerine göre bakış açılarının değiştiğini belirtmiştir. Öğretmenin, sınıf düzeyine göre öğrencilerin yapabileceklerini keşfettiği ve ona göre içerikleri uyguladığı ortaya çıkmaktadır. Ancak gözlem verilerinde öğrencilerin uygulama çalışmasının üstesinden gelmekte zorlandığı; bu nedenle öğrenciler akran desteğine yönelme, öğretmene bağımlılık duyma ve çalışmayı bitirmeme davranışlarını göstermiştir. Çalışma grubunda, sınıftaki tüm öğrencilerin çalışmasını 
tamamladığı bir ders bulunmamaktadır. Öğretmenler belirledikleri süre sonunda yeni konuya geçmiş ve bitmeyen çalışmalar tamamlanmak üzere ertelenmiştir. Bu durum ders içeriğinin belirlenmesi, öğrenciye aktarılması ve dersin planlanmasında aksaklıklar olduğunu ortaya koymaktadır. San'ın (2010) belirttiği üzere; sanat eğiticisi konuları, içerikleri ve belli yöntemleri niçin seçtiğini temellendirebilmeli, hangi amaca yöneldiğini saptayabilmelidir.

Araştırmanın üçüncü alt amacında öğretmenlerin ölçme ve değerlendirme sürecini nasıl gerçekleştirdikleri ele alınmıştır. Çalışma grubunda, sadece uygulama çalışması disiplinine yönelik değerlendirme yapıldığı gözlenmiştir. Öğrenciler çalışmalarını planlanan sürede bitiremediği için ölçme ve değerlendirme sürecine yer verilememiştir. Ayrıca öğretmenin yeni konuya başladıktan sonra, eş zamanlı olarak önceki çalışmaların değerlendirilmesine devam ettiği dersler gözlemlenmiştir. Mamur (2004), görsel sanatlar öğretmenleri ile yaptığı görüşmelerde süre yetersizliği nedeniyle değerlendirmenin yapılmadığı ya da aksaklıklar yaşandığ 1 sonucuna ulaşmıştır. Öğretmenler, öğrencinin derse olan ilgisini sürdürebilmek amaciyla çalışmanın tamamlanmasını ve öz düzenleme becerilerini ölçüt olarak kullandıklarını belirtmişlerdir. Öğrencinin çalışmayı tamamlaması tam not alması anlamına gelmektedir. Çakmak ve Türkcan'ın (2019) çalışmasında benzer olarak öğretmenler, düşük puanın öğrencinin derse olan ilgisini kaybetmesine neden olacağını düşündüklerinden genellikle iyi notlar verdiklerini belirtmişlerdir. Ölçme ve değerlendirme sürecinin hedef ve kazanımlarla ilişkilendirilmemesi, uygulama çalışmalarının gözlemlenebilir ölçütlerle ele alınamaması ve kuramsal bölümün ölçülmemesi gibi durumlar dersin planlanması ile ilgili eksiklikleri ortaya koymaktadır. Siegesmund (1998), "sanat eğitiminin, bilmeye değer bilgi ve deneyim kazandıran bir alan olarak kabul edilmedikçe okullarda program dıșı, az önemli bir alan olarak görülmeye devam edeceğini belirtmiştir.” (akt., Kırışoğlu, 2009, s. 16). Bu nedenle sanat eğitimi sürecinin tasarlanmasında, eğitimin genel hedeflerinden yola çıkılarak sistematik ve anlaşılır bir yaklaşımın benimsenmesi önemlidir.

Görsel sanatlar öğretmeninin ders sürecini, öğrencilerin zekasına, ilgilerine ve duygularına hitap edebilecek içeriklerle tasarlayabilmesi, farklı özellikte öğrencilere ulaşmasını ve öğrencilerin çok yönlü gelişmesini sağlayabilir. Bu nedenle mevcut fiziksel koşullara uygun görsel sanatlar dersi içeriğinin nasıl geliştirilebileceği ve diğer disiplinlerle ilişkilerin nasıl kurulabileceği sorularının ele alınması gerekmektedir. $\mathrm{Bu}$ nedenle Millî Eğitim Bakanlı̆̆ı'nda görsel sanatlar ders içeriklerine geri bildirimin verildiğì, sürecin geliştirilmesi ve sürdürülmesinin sağlandığı bir birimin oluşturulması önerilebilir. 2019 yılı Mart ayından itibaren dünyada yaygınlaşan Covid-19 salgını günlük yaşamı büyük ölçüde kısıtlamış; eğitim ve öğretim sürecinin çevrim içi ve uzaktan eğitim modellerine tamamen uyarlanmasını gerektirmiştir. Eğitimin her düzeyinde oluşan bu ani değişim özellikle uygulamalı alanlara yönelik eğitim etkinliklerinin sürdürülmesinde aksaklık ve eksiklikler ortaya çıkarmıştır. Diğer taraftan çevrim içi ve uzaktan eğitim uygulamaları, eğitimde teknoloji kullanımına daha çok gereksinim duyulan ve hızlı çözümlerin üretildiği süreci de beraberinde getirmiş̧ir. Bu araştırmada, yüz yüze 
yapılan görsel sanatlar dersi, kuramsal bilginin aktarılması, tasarım süreci, uygulamalı çalışmalar, ölçme ve değerlendirme kategorileri altında incelenerek karşılaşılan sorunlar ortaya çıkarılmıştır. Yüz yüze derslerde karşılaşılan bu sorunların çözümünde Covid-19 döneminde kazanılan teknoloji destekli çözümlerden daha fazla yararlanılabilir. Bu anlamda yüz yüze ve çevrim içi olarak deneyimlenen görsel sanatlar dersinin güçlü ve zayıf yönlerinin araştırılması gerekmektedir. Böylece dersin işlenişinde her iki yöntemin uygulanabileceği yeni bir görsel sanatlar dersi yaklaşımı oluşturularak alanın geliştirilmesi sağlanabilir. Ayrıca üniversiteler, okul dışı öğrenme alanları, sanatçılar, sivil toplum örgütleri gibi pek çok yapının öğretmenle işbirliği içinde, öğrencilerin yetiştirilmesi konusunda destek olabileceği düşünülmektedir. Böylece bilinçli sanat izleyicisinin yetiştirilmesi ve toplumda sanat bilincinin oluşturulmasında sanat eğitiminin katkısı dikkate alınarak eğitim sistemi içerisinde önemli bir gereksinim olduğu anlaşılabilir.

\section{Etik Kurul Kararı}

$\mathrm{Bu}$ araştırma, Ankara Üniversitesi etik kurul onayına (No: 85434274 050.04.04/27013, Tarih: 25.04.2019) sunulmuştur.

\section{Kaynakça}

Anderson, T., and Milbrandt, M. (1998). Authentic instruction in art: Why and how to dump the school art style. Visual Arts Research, 24(1), 13-20. Retrieved from https://www.jstor.org/stable/20715931

Aykut, A. (2012). Sanat eğitiminde estetik. İstanbul: Hayalperest Yayınevi.

Christensen, L. B., Johnson, R., B. and, Turner, L. A. (2015). Araştırma yöntemleri desen ve analiz [Research Methods Design and Analysis]. (M. Sever, Çev.). A. Aypay (Ed.), Nitel ve karma yöntem araştırmaları içinde (ss. 401-434). Ankara: Anı Yayıncilık. (2014)

Cömert, S. A. (2019). Görsel sanatlar öğretmenlerinin karşılaştıkları problemler ve çözüm önerileri. EKEV Akademi Dergisi, 23(78), 497-510. http://www.ekevakademi.org/Makaleler/365163437_27\%20Sibel\%20ADAR\% 20COMERT.pdf adresinden erişilmiştir.

Çakmak, N. ve Türkcan, B. (2019). Değişmeyen algılar, değişmeyen sorunlar: öğrenci-öğretmen-veli bağlamında ilkokul görsel sanatlar dersi. Eğitimde Nitel Araştırmalar Dergisi, 7(2), 768-791. doi: 10.14689/issn.2148-2624.1.7c.2s.13m

Dewey, J. (1938, 1998). Deneyim ve eğitim [Experience and education]. (S. Akıllı, Çev.). Ankara: ODTÜ Yayıncılık. (2007).

Eisner, E. (2001). Should we create new aims for art education? Art Education, 54(5), 6-10. doi: 10.2307/3193929 
Fisher, R. (1999). Thinking skills to thinking schools: Ways to develop children's thinking and learning. Early Child Development and Care, 153(1), 51-63. doi: $10.1080 / 0300443991530104$

Freedman, K., and Stuhr, P. (2004). Curriculum change for the 21st century: Visual culture in art education. In E. Eisner and M. D. Day (Eds.), Handbook of research and policy in art education (pp. 815-828). New York: Routledge.

Gözütok, F. D. (2017). Öğretim ilke ve yöntemleri. Ankara: Pegem Akademi.

Gude, O. (2007). Principles of possibility: Considerations for 21 st-century art \& culture curriculum. Art Education, 60(1), 6-17. Retrieved from https://www.jstor.org/stable/27696187

Karip, E. (2016, 9 Haziran). Dördüncü sanayi devrimi ve eğitim. https://tedmem.org/vurus/dorduncu-sanayi-devrimi-egitim adresinden erişilmiştir.

Kırışoğlu, O. T. (2005). Sanatta eğitim görmek, ögrrenmek, yaratmak. Ankara: Pegem Yayıncilik.

Kırışoğlu, O. T. (2009). Sanat, kültür, yaratıcılık: Görsel sanatlar ve kültür eğitimiögretimi. Ankara: Pegem Akademi.

Korkutal, P. (2010). Resim-iş eğitimi anabilim dallarında görsel belleğin gelişimine yönelik ögretim etkinlikleri ile görsel algı ilişkileri (Yayımlanmamış yüksek lisans tezi). Dokuz Eylül Üniversitesi Eğitim Bilimleri Enstitüsü, İzmir.

Mamur, N. (2004). Çok alanlı sanat eğitiminde ölçümleme ve değerlendirme yaklaşımları: Bolu ili örneği. Illköğretim Online, 3(2), 1-18. https://www.ilkogretim-online.org/fulltext/218-1596616300.pdf?1636361032 adresinden erişilmiştir.

Merriam, S. B. (2013). Nitel araştırma desen ve uygulama için bir rehber [Qualitative research: A guide to design and implementation]. (S. Turan, Çev.). Ankara: Nobel Akademik Yayıncılık. (2009)

Milli Eğitim Bakanlığı (2006). Görsel sanatlar dersi (1-8. sinıflar) öğretim programı ve kılavuzu. Ankara: MEB Devlet Kitapları Müdürlüğü.

Milli Eğitim Bakanlığı. (2018). Görsel sanatlar dersi ögretim programı (ilkokul ve ortaokul 1-8. sinıflar). Ankara: Milli Eğitim Bakanlığı.

Namdar, A. O. ve Önder, V. (2019). Türkiye'de ilköğretimde görsel sanatlar ile ilgili yapılan lisansüstü tezlerin eğilimleri. Kastamonu Eğitim Dergisi, 27(2), 767784. doi: 10.24106/kefdergi.2719

Özsoy, V. (2007). Görsel sanatlar eğitimi, resim-iş eğitiminin tarihsel ve düşünsel temelleri. Ankara: Gündüz Eğitim ve Yayıncılık. 
Robinson, D., and Aronica, L. (2017). Yaratıcı öğrenciler çocukların geleceğini düşünenler için eğitimde yaratıcılık devrimi [Creative schools: The grassroots revolution that's transforming education]. (D. Boyraz, Çev.). İstanbul: Sola Yayınları. (2015)

San, İ. (2010). Sanat eğitimi kuramları. Ankara: Ütopya Yayınevi.

Sarı, N. H. (2011). İlköğretim görsel sanatlar dersi ögretim programinin kuramsal yapı ve uygulanabilirlik açısından değerlendirmesi (Yayımlanmamış doktora tezi). Gazi Üniversitesi Eğitim Bilimleri Enstitüsü, Ankara.

Schunk, D. H. (2011). Yapılandırmacı teori [Constructivism] (M. Y. Demir, Çev.). M. Şahin (Ed.), Öğrenme teorileri, eğitimsel bir bakuşla [Learning theories: An educational perspective]. Ankara: Nobel Akademi. (1990)

Yıldırım, A. ve Şimşek, H. (2008). Sosyal bilimlerde nitel araştırma yöntemleri (6. Baskı). Ankara: Seçkin Yayıncılık.

Yılmaz, S. (2017). Görsel sanatlar öğretmenlerinin motivasyon stratejilerine iliş̧kin beklentiler. 21. Yüzyllda Eğitim ve Toplum, Eğitim Bilimleri ve Sosyal Araştırmalar Dergisi, $\quad$ 6(17), https://dergipark.org.tr/tr/pub/egitimvetoplum/issue/35909/402846 adresinden erişilmiştir. 


\title{
Teacher Experiences Regarding the Teaching and Learning Process of the Secondary School Visual Arts Lesson $^{1}$
}

\begin{tabular}{cccc}
\hline ARTICLE TYPE & Received Date & Accepted Date & Published Date \\
Research Article & 04.09 .2021 & 11.14 .2021 & 11.15 .2021 \\
\hline
\end{tabular}

\author{
Nergiz Üçüncü Altuğ iD ${ }^{2}$ \\ Uludag University
}

\author{
Ayşe Çakır İlhan (iD ${ }^{3}$ \\ Ankara University
}

\begin{abstract}
Visual arts lesson, with its theoretical and applied structure, aims to offer level-appropriate content for students to ensure their personal, social and cultural development. Not only does it foster the interpretation of knowledge through the theoretical disciplines of art history, art criticism and aesthetics, but it also triggers the production of self-expression through art practice. In this way, it contributes to formulating awareness and consciousness towards the arts. In this research, I thoroughly examined the experiences of 13 visual arts teachers during teaching and learning process, art production and measurement and evaluation activities at secondary schools in Ankara and Bursa. I organized this study around the principles of the fundamental qualitative method and thus focused on the analysis and interpretation of teaching and learning process in class. I have collected the qualitative data via semi-structured interviews and observations. Then I thoroughly analyzed them with an aim to create research-related concepts by using the stages of the qualitative content analysis technique. As a result, I reached some findings on the use of discipline-based art education, development of design and selfexpression, topic selection during art practice and its appropriateness to student level, and the implementation of assessment and evaluation activities. At the end of the study, I also made some recommendations for further improvements in the field of visual arts education. For instance, visual arts teachers should be supported in preparing interdisciplinary lesson plans and setting out to organize activities in accordance with the existing physical learning environment.
\end{abstract}

Keywords: Art education, visual arts education, secondary school, visual arts teacher.

Ethical committee approval: Ethical consent was obtained from Ankara University Ethical Committee, No: 85434274-050.04.04/27013, Date:25.04.2019.

\footnotetext{
${ }^{1}$ This article is derived from $\mathrm{PhD}$ dissertation entitled "Development of occupational improvement module for visual arts instructors" conducted under the supervision of Prof. Dr. Ayşe Çakır İlhan at Ankara University Institute of Educational Sciences.

${ }^{2}$ Corresponding Author: Res. Assist., Faculty of Education, Departmant of Fine Arts Education, E-mail: nergizucuncu@gmail.com, https://orcid.org/0000-0002-9975-9302

${ }^{3}$ Prof. Dr., Faculty of Educational Sciences, Departmant of Fine Arts Education, E-mail: ilhan@ankara.edu.tr, https://orcid.org/0000-0003-1236-711X
} 


\section{Purpose and Significance}

In this study, my aim was to investigate visual arts teachers' experiences in depth during the teaching and learning process at secondary schools. Visual arts lesson has a broad background that takes its source from arts and culture. In this manner, it does not only cover the intellectual foundations of art, concepts and analysis of art-making process but also -and most importantly-it enables the interpretation and production of information (Aykut, 2012). The role of visual arts lesson in developing a person's learning capacity in affective, cognitive and psychomotor domains and enhancing higher-order thinking skills is highly critical. However, there seems to be a constant contradiction between theory and practice in terms of the implementation process of visual arts lesson. Kırışoğlu (2005) states that art education emerges as a field where there is a constant contradiction between the current state and ideal conditions. Therefore, it is necessary that we evaluate art education providers and institutions with their existing problems and possible solutions embedded in their experiences instead of criticizing the education system's exam-based structure for being the source of this contradiction.

In the literature, it is widely emphasized that we should improve the physical conditions of workshops and regulate the lesson hours accordingly. Also, problems regarding pre-service teacher education and attitude towards visual arts are signified in various research studies. However, it is also necessary to investigate what is experienced in visual arts lessons during the teaching and learning process. With this in mind, I specified the subgoals of this research study as theoretical part of the lesson, art practice and measurement and evaluation activities. In this way, I managed to reveal the physical disadvantages experienced in visual arts classes and problems encountered in lesson content. For this reason, I conducted long-term fieldwork to thoroughly analyze the problems and their possible solutions.

\section{Method}

This study was organized around the principles of the fundamental (interpretive) qualitative method to be able to focus on the analysis and interpretation of teaching and learning process in class. With this in mind, I used the convenience sampling technique to reach teachers and schools that were easily accessible and convenient to me as the researcher. In this context, ten public secondary schools from various socioeconomic levels were involved in the study from Ankara and Bursa. Finally, the study group consisted of 13 visual arts teachers willing to voluntarily participate in research. Qualitative data was collected via semi-structured interviews and observations after obtaining expert opinions regarding the quality of data collection tools. As a final step, the pilot study began in Ankara and Bursa, followed by the actual fieldwork.

After verbatim transcription of qualitative data, I used the stages of content analysis to create new concepts. Based on my research problem, I examined the transcripts within the scope of the needs of visual arts class and made open coding by taking notes. Later, I grouped the open codes related to each other and reached some categories. It was aimed to include teachers from diverse backgrounds with a variety 
of professional experience in order to ensure validity. Besides, schools were selected from a wide range of socio-economic backgrounds to enable transferability of the research results. The triangulation strategy was addressed by using more than one data collection technique to increase the internal validity of the study. Also, a qualitative research field expert examined the consistency of the coded data. Lastly, long-term interaction was provided to assure the internal validity of the study. Findings were presented by enriching them with direct quotations of the participants without any researcher interpretation.

\section{Results}

As a result of this study, I reached some findings regarding visual arts teachers' professional learning needs on the use of discipline-based art education, development of design and self-expression, conducting the process of art practice and completing it in a specified time period, and the implementation of assessment and evaluation activities. It can be an effective strategy for visual arts teachers to design lesson activities that attract students' interests, meet their varying emotional and cognitive needs for their holistic development. We need to address the problems of how to develop the content of visual arts lesson and how to connect it with other disciplines. Siegesmund (1998) warns that "unless art education is accepted as a field of study providing knowledge and experience that is worth knowing, it will unfortunately continue to be regarded as a non-curricular or less important subject at school" (as cited in Kırışoğlu, 2009, p. 16). For this reason, it is essential to adopt a systematic and comprehensible approach in the design of the arts education based on the general aims of education.

\section{Discussion and Conclusions}

In this study, I investigated the teaching and learning process of visual arts lesson at secondary schools and presented the results in categories formed in the framework of my subgoals. The first subgoal is about how the theoretical part of the lesson is carried out. Teachers stated that they did not include art history in the theoretical part of the lesson, as students did not wish to learn topics that included narration. Teachers signified that art criticism and aesthetic disciplines did not attract students' attention. It was also vivid that teachers need professional support about how to plan lessons in line with students' level. Results of this study signify that teachers predominantly design their lesson plans around art practice. However, Özsoy (2007) emphasizes that it is crucial that we include all art disciplines consisting of art history, art criticism, aesthetics and art practice. Also, results show that teachers generally are not able to reach out to all students when they use the demonstration technique. A way of overcoming this challenge can be for teachers to project the images on smart board or prepare a guidance video to show students during demonstration activity.

In the theoretical part of the lesson, teachers were very cautious when they used the sample visuals and covered the images. This was one of the most interesting findings of this research. Teachers thought that using sample visuals would diversify and develop students' ideas; however, it caused students to stick to the examples and 
not act or think beyond them in their art production process. Kırışoğlu (2005) points that exemplary work from previous artists, nature and all kinds of visual resources could be used to create values and solve problems during art practices. In this sense, showing sample visuals can be implemented with activities that can provide ideas and nurture students' design thinking.

Teachers generally expect students to spontaneously reveal their creativity during the design process, which enables students to make intellectual and linear planning. Also, topics that only aim at improving technical skills, handicrafts, or vision training have the potential to prevent the formation of design and selfexpression. If a visual arts lesson only focuses on technical knowledge transmission, then the learning is highly limited to linear instructions reflecting the traditional perspective. Gude (2007) advises that students should not only learn to deal with material, but they should also learn to create new ideas. I realized that teachers wanted students to strictly follow their steps during class demonstrations. In a way, all students are expected to take the same steps and reach the same result with a specific technique and sequence. However, Yilmaz (2017) concludes that choices are quite influential in shaping students' beliefs. Therefore, content and technical diversity should be nurtured instead of following a single content and a single technique.

The second subgoal of the study is about how teachers perform the art practice in the classroom. Teachers signified that they usually chose topics by taking students' abilities into account during activities, and therefore they learned to choose content by trial and error. However, it was observed that students preferred working in pairs as they had difficulty coping with the practical work. As a result, students were inclined to show dependency on their teachers and mostly could not finish the art practice in time. Even though students could not finish the art work, teachers switched to a new topic at the end of the period they determined, and the unfinished studies were postponed to be completed another time. This situation indicates some problems in choosing content, lesson planning and implementation. As San (2010) states, art educators should be able to specify the rationales for choosing a specific content and method, and reflect on these decisions.

The third subgoal of the study is about how teachers carry out the assessment and evaluation process. In this study, only the art practice of the visual arts lesson was evaluated via observations. However, assessment and evaluation findings are not included in this paper, as students could not end up their practice works on time. Also, it was observed that teachers allocated some time to evaluate students' works even after starting the new topic. Mamur (2004) conducted interviews with visual arts teachers and concluded that the evaluation part was not included due to the shortage of time. Teachers use work completion and self-regulation skills as grading criteria to maintain student's interest in the lesson. If students can finish their practice work on time, it means that they can get full marks. Similarly, Çakmak and Türkcan (2019) reveal that teachers generally give high grades with a fear that low grades might decrease student motivation and integration in visual arts lesson. 
In sum, measurement and evaluation process is not associated with the goals and objectives of the lesson and implementation is not handled by observable criteria. Also, the theoretical part of the visual arts lesson is not measured and evaluated. Therefore, these findings clearly show that teachers need professional learning support in lesson planning and evaluation.

\section{Ethical Committee Approval}

Ethical consent was obtained from Ankara University Ethical Committee, No: 85434274-050.04.04/27013, Date:25.04.2019. 